\title{
Microbes-Coated Urea for Reducing Urea Dose of Strawberry Early Growth in Soilless Media
}

\author{
Reginawanti Hindersah ${ }^{1, *}$, Indyra Rahmadina ${ }^{2}$, Betty Natalie Fitriatin ${ }^{3}$, Mieke \\ Rochimi Setiawati ${ }^{2}$, Diky Indrawibawa ${ }^{3}$ \\ ${ }^{1}$ Faculty of Agriculture, Universitas Padjadjaran, Jalan. Raya Bandung-Sumedang Km. 21, Jatinangor, Sumedang 45363, Indonesia \\ ${ }^{2}$ Graduated from Agrotechnology Undergraduate Program, Faculty of Agriculture, Universitas Padjadjaran, Indonesia \\ ${ }^{3}$ Bumi Agrotechnology Farm, Kp. Kebon Cau, Jalan Mekartani, Kertawangi Village, Cisarua District, Bandung Barat Regency, Indonesia
}

Received: February 27, 2021; Revised: May 17, 2021; Accepted: July 19, 2021

\begin{abstract}
Strawberry is a high-value fruit in Indonesia. During the growth phase for transplant production, farmers applied conventional urea that is easy to volatile and leach. Coated Urea has proven to reduce nitrogen (N) losses from urea fertilizer. Microbial-coated urea application is a reliable way to limit the loss of $\mathrm{N}$ from urea and at the same time increase the use of biofertilizer. Azotobacter and Bacillus are widely used as a biofertilizer formulation. This experimental objective was to determine the effect of two formulations and doses of urea coated with solid organic inoculant of Azotobacter and Bacillus on the growth parameters of strawberry seedling as well as reducing urea fertilizer. The green house experiment was carried out in randomized completely block design (RCBD) with five treatments and five replications. One-month old strawberry cv Festival seedlings were grown in coco peat based organic substrate. The seedlings were treated with four combinations of two doses and formulation of microbial coated urea (MCU). Control seedlings received a dose of conventional prilled urea. The results showed that MCU affected root dry weight, root volume, root to shoot ratio, SPAD value, and $\mathrm{N}$ uptake but did not significantly affect shoot parameters compared to controls. The best composition of urea coated material was compost-based inoculant enriched with 5\% zeolite and 5\% liquid inoculant. Moreover, this experiment explained that microbial-coated urea might replace $50 \%$ of conventional urea.
\end{abstract}

Keyword: Bacteria coated Urea, Azotobacter sp., Bacillus sp., Zeolite, Fertilizers doses, Strawberry growth

\section{Introduction}

Strawberries (Fragaria $\times$ Ananassa Duch) grow well in Indonesian mountainous area with good physical soil properties. Farmers in high land Bandung and Bandung Barat Regency cultivate the strawberries since decade ago with significant economic benefit. Strawberry productivity and quality in Indonesian high land are limited by the nutrients management. In general, farmers propagate the strawberry from runner, well known as stolon, that grow above the ground. The new clone will grow and can be separated from the mother plant once the stolon roots touch the soil.

Some strawberry producers have carried out strawberry nurseries to produce strawberry using soilless growth media composed of coco peat and manure (Ameri et al., 2012; Raja et al., 2018). Compared to soil, this medium contains only a few nutrients but its physical properties are good for rooting. Farmers in Bandung Regency applied chemical fertilizer, urea and NPK compound as well, to provide nutrient during bare-root strawberry transplant production.

The disadvantage of using urea is ammonia volatilization at high temperatures environment (Fan et al., 2011; Jadon et al., 2018). Increasing temperature from 20 to $30{ }^{\circ} \mathrm{C}$ enhanced $\mathrm{NH}_{3}$ volatilization with higher loss recorded in sandy soil than loamy soil (Fan et al., 2011). Urea can be easily leaching from root zone since the precipitation is higher over the water holding capacity (Burger and Jackson, 2003; Wang et al., 2015). To overcome the constraints, coated urea has been recommended as a reliable way to slow and control $\mathrm{N}$ release from urea (Bibi et al., 2016). Ground application of neem-and oleoresin-coated urea reported to reduce the ammonia volatilization and nitrate leaching significantly (Jadon et al., 2018).

We have limited information about fertilizer/urea coated with beneficial microbes. Researchers have shown the effectivity of microbes-coated urea (MCU) to reduce the level of chlorinated pesticide and the persistent organic pollutant in soil (Wahyuni et al., 2016). Ahmad et al (2017) stated that bacterial-impregnated ammonium phosphate enhancing nitrogen $(\mathrm{N})$ and phosphorus $(\mathrm{P})$ use efficiency of wheat. Coating urea with soil beneficial microbes such as the $\mathrm{N}$-fixing Azotobacter and the phosphate solubilizing Bacillus is also a way to enhance the beneficial microbe application. Azotobacter and Bacillus are the active ingredients of biofertilizer suggested to provide nutrients and ensure plant growth through $\mathrm{N}$ fixation and phosphate solubilization respectively (Rubio et al., 2013; Saeid et al., 2018). Both

\footnotetext{
* Corresponding author e-mail: reginawanti@unpad.ac.id.
} 
rhizobacteria produced phytohormones of auxins cytokinins, gibberellins (Fitriatin et al. 2020; Hindersah et al., 2019; Hindersah et al. 2020a) which is beneficial to stimulate root and subsequent plant growth (Bhattacharyya and Jha. 2012). The Azotobacter and Bacillus form cysts and spores (Rodriguez-Salazar et al., 2017; Tan and Rammurthi, 2014) as a response to drought stress. However, farmers in Indonesia are rarely including the biofertilizer in their nutrient management since the labor cost will increase when the biofertilizer is applied separately from the urea. Coating urea with the microbes might overcome this constraint.

Nitrogen and $\mathrm{P}$ are essential macronutrients and determine plant productivity. The advantage of $\mathrm{N}$-fixer Azotobacter and P-solubilizer Bacillus inoculation in strawberry cultivation have been documented to increase significant growth and yield in field and greenhouse as well (Mishra and Tripathi, 2011; Shternshis et al., 2015; Reddy and Goyal, 2021). Moreover, Bacillus can control the diseases and induce plant resistance to the strawberry diseases (Shternshis et al., 2015; Wei et al., 2016).

We have already developed a mixed liquid biofertilizer containing A. chroococcum, A. vinelandii, B. subtilis and $B$. megaterium with the equal composition to maintain each bacterial population up $10^{8} \mathrm{CFU} / \mathrm{ml}$ (Hindersah et al., 2020b). For coating the urea, a solid inoculant is needed to avoid direct intact with urea and ensure the bacterial viability since the water content of urea is as low as $0.5 \%$.

Based on previous research, an effective carrier for maintaining the population of both microbes was 200mesh compost enriched with 100-mesh zeolite at 15\% moisture content (Hindersah et al., 2020a). The level zeolite and liquid inoculant in solid inoculant formultion is also essential prior to urea coating. Furthermore, compostbased solid inoculant with $5 \%$ Zeolite $+5 \%$ Liquid as well as $1 \%$ zeolite and $10 \%$ liquid Inoculant supported Azotobacter and Bacillus count at $10^{9}$ and $10^{11} \mathrm{CFU} / \mathrm{g}$ respectively during 4 weeks of storage (Hindersah et al., 2021). In the formulation described above, the molecule structure of zeolites functions in adsorbing water (Tatlier et al, 2018) to maintain low water content in carrier and further coated urea fertilizer.

Biofertilizers are now integrated in horticultural crops production for decreasing the level of chemical fertilizer and increasing the soil health. However, the price of microbial-coated urea might be higher over the conventional urea. The use of coated urea will be efficient for high value horticultural products such as strawberry in Bandung Regency, and then research to optimize the application of these newer coated urea is needed. The effectiveness of the urea coated with Azotobacter-Bacillus consortium on the growth of strawberry seedlings, especially the morphological parameters, needs to be verified prior to the wider use by the farmers. The objective of this greenhouse experiment was to determine the effect of solid inoculant-coated urea on the growth properties of strawberry seedlings grown in soilless media for 4 weeks during bare-roots strawberry seedling production.

\section{Material and Methods}

Greenhouse trials were conducted from October 2019 to March 2020 at Bumi Agrotechnology Farm in Cisarua,
Bandung Barat Regency at the altitude of 1,225 $\mathrm{m}$ above sea level. The location situated in tropics with average annual temperature $17-26^{\circ} \mathrm{C}$ and humidity $70-90 \%$. Urea was coated with solid inoculant of $\mathrm{N}$-fixing $A$. vinelandii and $A$. chrococcum, and phosphate-solubilizing $B$. subtilis and $B$. megaterium consortia developed by the Soil Biology Laboratory Faculty of Agriculture, Universitas Padjadjaran. Liquid inoculant of all bacteria was prepared in molasses based broth enriched with $\mathrm{N}$ source (Hindersah et al., 2020b). The Azotobacter and Bacillus produced phytohormone of indole acetic acid (IAA), cytokinins (CK) and gibberellins (GA) in the in-vitro test (Hindersah et al., 2020b). The seedlings of strawberry cv. Festival were provided by Bumi Agrotechnology Farm. Four-week old daughter plants of strawberry growing on the tip of stolon have been separated from the mother plant at planting time (Fig 1).

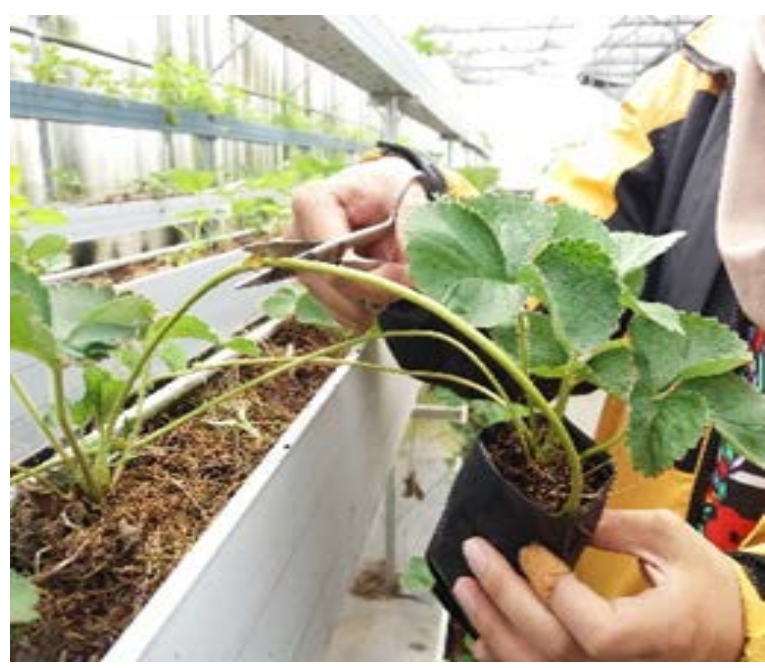

Figure 1. One-month old strawberry seedlings before being cutting from the mother plant and transplant.

\subsection{Experimental Establishment}

The experiment was setup in completely randomized block design with 5 treatments consisting of 4 combinations of doses and composition of MCU and one control treatment (Fig 2); all treatments were replicated 5 times. Based on previous experiment, two best formulations of solid bacterial inoculant for coating the urea are:

1. 200-mesh cow manure compost enriched with $5 \%$ of

100-mesh zeolite and 5\% of mixed liquid Inoculant of

Bacillus and Azotobacter (composition I) and

2. 200-mesh cow manure compost enriched with $1 \%$

zeolite $+10 \%$ liquid inoculant (composition II).

The MCU treatments were the combination of each formula with full and half application doses, so that we have 4 combination treatments of Microbial coated urea (MCU). The doses of MCU were based on the recommended urea dose for strawberry released by Indonesian Agricultural Research and Development Institute, i.e. $200 \mathrm{~kg} / \mathrm{ha}$ equal to $2 \mathrm{~g}$ /plant. Plant with full and half doses received $1 \mathrm{~g}$ and $2 \mathrm{~g}$ of urea respectively. The control treatment was $2 \mathrm{~g}$ of conventional prilled urea.

The 14-cm height of strawberry seedling cv Festival with 5 leaves and 18-20 cm in crown diameter were grown in the substrate contained mixed of coco peat, chicken and sheep manure at volume ratio of 8:2:1. The substrates were 
average in $\mathrm{N}(0.57 \%)$, and very low in $\mathrm{P}_{2} \mathrm{O}_{5}(0.035$ $\mathrm{mg} / \mathrm{kg})$ and $\mathrm{K}_{2} \mathrm{O}(0.26 \mathrm{mg} / 100 \mathrm{~g})$ with the $\mathrm{C} / \mathrm{N} 39.74$. The media were put in $40 \times 40 \mathrm{~cm}$ polyethylene bag and placed in the greenhouse for a week prior to transplant with two strawberry seedlings. One week after transplanting, strawberry seedlings received the MCU that incorporated with the first two $2-\mathrm{cm}$ depth at $10 \mathrm{~cm}$ next to the base crown. Inorganic NPK fertilizer (16:16:16) at the rate of 2 g/plant (Palupi et al., 2017) was applied two weeks after planting to all treatments. The fertilizer was placing on the circle about $10 \mathrm{~cm}$ away from the base crown and covering with the growth medium.

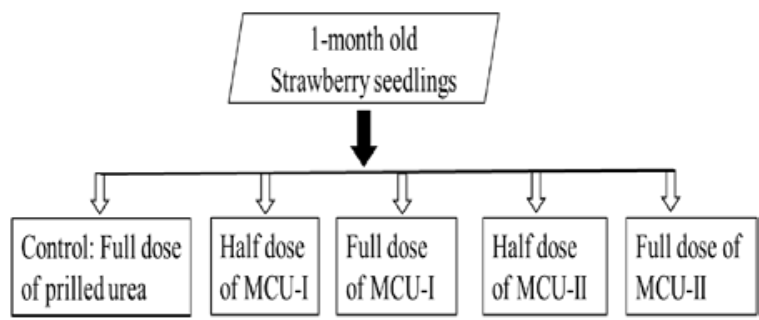

Figure 2. The experimental treatments of microbial coated urea (MCU) application in strawberry seedlings cultivation

\subsection{Parameters Measurement}

All plants were maintained in the greenhouse for 4 weeks. The data of plant height, root length, crown diameter, root dry weight, root volume, shoot dry weight, root to shoot ratio, chlorophyll unit, as well as $\mathrm{N}$ content and $\mathrm{N}$ uptake of shoot were taken at the end of trial. Nitrogen uptake represent their accumulation in crops as well as N availability in soil (Gastal and Lemaire, 2002). Root and shoot biomass were dried separately in oven at $70{ }^{0} \mathrm{C}$ for two days until constant weight prior to dry weight measurement. Root volume was determined by Water Displacement Method (Pang et al., 2011); roots were immersed in $100 \mathrm{~mL}$ water in graduated cylinder with $0.1 \mathrm{ml}$ accuracy measurement. The water volume increment after root immersion was suggested as the roots volume. The crown (thickened stem) diameter of strawberry seedlings was measured from the upper end of the crown using a caliper with $0.1 \mathrm{ml}$ accuracy.

Chlorophyll value of strawberry foliage were estimated using a Soil Plant Analysis Development (SPAD-502) chlorophyll meter (Güler et al., 2006) for the six points in five leaves below the fully opening leaves on the top of shoot. The N content of shoots was analyzed by Kjeldahl Method based on Association of Official Analytical Chemists (AOAC) methods for proximate analysis (AOAC, 2012). The $\mathrm{N}$ uptake of shoots was calculated by multiplying the $\mathrm{N}$ content of shoot with the shoot dry weight.

\subsection{Statistical Analysis}

All data were subjected to analysis of variance (F test with $\mathrm{p} \leq 0.05$ ) to verify the significant of sum square on the parameters. The Duncan's multiple range test $(\mathrm{p} \leq 0.05)$ was then performed when $\mathrm{F}$ test was significant. The data were analyzed with IBM SPSS statistics version 25 (Mustafa and Hayder, 2021)

\section{Results}

MCU-I refers to coated urea with compost-based biofertilizer formulated enriched with $5 \%$ zeolite enrichment and inoculated with 5\% mixed AzotobacterBacillus liquid Inoculant, whereas MCU-II is coated urea with compost-based biofertilizer with $1 \%$ zeolite and $10 \%$ liquid inoculant.

\subsection{Root Parameters}

The different dose of MCU integrated with different composition of solid inoculant for coating the urea has not affected the roots length but some treatments increased root dry weight and volume as compared with the control (Table 1). Strawberry seedling received $1 \mathrm{~g}$ of urea coated with solid inoculant contained 5\% zeolite and 5\% liquid inoculant (MCU-I) have highest root dry weight compared to the control and other treatments after 4 weeks in soilless substrate. The root volume of seedling received $1 \mathrm{~g}$ urea coated with solid inoculant contained $1 \%$ zeolite and $10 \%$ liquid inoculant (MCU-II) was higher than other treatments but their root dry weight was slightly lower than seedling with $1 \mathrm{~g}$ MCU-I.

Table 1. The effect of dose and microbes-coated urea on roots length dry weight and volume of four-week old strawberry grown in the greenhouse.

\begin{tabular}{llll}
\hline & \multicolumn{3}{l}{ Root Parameters } \\
\cline { 2 - 4 } Coated Urea Treatments & $\begin{array}{l}\text { Lenght } \\
(\mathrm{cm})\end{array}$ & $\begin{array}{l}\text { Dry weight } \\
(\mathrm{g})\end{array}$ & $\begin{array}{l}\text { Volume } \\
(\mathrm{ml})\end{array}$ \\
\hline 2 g of Prilled Urea (control) & $25.3 \mathrm{a}$ & $2.7 \mathrm{~b}$ & $103.2 \mathrm{c}$ \\
1 g of Microbial Coated Urea -I & $25.8 \mathrm{a}$ & $5.7 \mathrm{a}$ & $110.5 \mathrm{~b}$ \\
2 g of Microbial Coated Urea -I & $25.0 \mathrm{a}$ & $5.1 \mathrm{a}$ & $109.3 \mathrm{~b}$ \\
1 g of Microbial Coated Urea -II & $25.2 \mathrm{a}$ & $4.4 \mathrm{ab}$ & $114.2 \mathrm{a}$ \\
2 g of Microbial Coated Urea -II & $27.8 \mathrm{a}$ & $2.9 \mathrm{~b}$ & $107.5 \mathrm{~b}$ \\
\hline
\end{tabular}

Numbers followed by the same letter didn't significantly differ based on Least Significant Test $(p<0.05)$. aCoated urea with compost-based biofertilizer contained $5 \%$ zeolite $+5 \%$ liquid inoculant; bCoated urea with compost-based biofertilizer contained $1 \%$ zeolite $+10 \%$ liquid inoculant.

\subsection{Shoot Parameters}

The results verified that the dose of urea coated with different composition of solid bacterial inoculant has not affected all measured shoot parameter (Table 2). However, reducing the dose of MCU to $50 \%$ resulted in equal shoot height and dry weight as well as crown diameter.

Tabel 2. The effect of dose and microbes-coated urea on shoot height and dry weight, and crown diameter of four-week old strawberry grown in the greenhouse

\begin{tabular}{llll}
\hline & \multicolumn{3}{l}{ Shoot Parameters } \\
\cline { 2 - 4 } Coated Urea Treatments & $\begin{array}{l}\text { Dry Weight } \\
\text { (gr) }\end{array}$ & $\begin{array}{l}\text { Height } \\
(\mathrm{cm})\end{array}$ & $\begin{array}{l}\text { Crown } \\
\text { Diameter } \\
(\mathrm{cm})\end{array}$ \\
\hline 2 g of Prilled Urea (control) & $2.7 \mathrm{a}$ & $22.2 \mathrm{a}$ & $2.4 \mathrm{a}$ \\
1 g of Microbial Coated Urea -I $\mathrm{I}^{\mathrm{a}}$ & $3.1 \mathrm{a}$ & $21.3 \mathrm{a}$ & $2.4 \mathrm{a}$ \\
2 g of Microbial Coated Urea -I & $2.5 \mathrm{a}$ & $20.5 \mathrm{a}$ & $2.9 \mathrm{a}$ \\
1 g of Microbial Coated Urea -II & $2.6 \mathrm{a}$ & $20.6 \mathrm{a}$ & $2.4 \mathrm{a}$ \\
2 g of Microbial Coated Urea -II & $2.8 \mathrm{a}$ & $20.2 \mathrm{a}$ & $2.5 \mathrm{a}$
\end{tabular}

Numbers followed by the same letter didn't significantly differ based on Least Significant Test $(\mathrm{p}<0.05)$. ${ }^{\mathrm{a}}$ Coated urea with compost-based biofertilizer contained $5 \%$ zeolite $+5 \%$ liquid inoculant; ${ }^{\mathrm{b}}$ Coated urea with compost-based biofertilizer contained $1 \%$ zeolite $+10 \%$ liquid inoculant. 


\subsection{Root to shoot ratio}

The ratios of root to shoot dry weight $(\mathrm{R} / \mathrm{S})$ of strawberry were significantly different among the treatments. Application of $1 \mathrm{~g}$ of MCU-I clearly resulted in higher R/S of the plant (Table 3). The R/S mostly $>1$ revealed that the root growth was more rigorous than shoot growth. Nonetheless, seedlings treated with either recommended-dose urea or $2 \mathrm{~g}$ of MCU-II have R/S $<1$.

Tabel 3. Change in root to shoot ratio of 4-week old strawberry in the greenhouse after different dose and microbes-coated urea application

\begin{tabular}{lc}
\hline Coated Urea Treatments & Root to Shoot Ratio \\
\hline 2 g of Prilled Urea (control) & $0.96 \mathrm{c}$ \\
1 g of Microbial Coated Urea-I ${ }^{\mathrm{a}}$ & $2.53 \mathrm{a}$ \\
2 g of Microbial Coated Urea-I & $1.86 \mathrm{~b}$ \\
1 g of Microbial Coated Urea -II & $1.74 \mathrm{~b}$ \\
2 g of Microbial Coated Urea -II & $0.94 \mathrm{c}$ \\
\hline
\end{tabular}

Numbers followed by the same letter didn't significantly differ

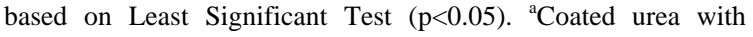
compost-based biofertilizer contained $5 \%$ zeolite $+5 \%$ liquid inoculant; ${ }^{\mathrm{b}}$ Coated urea with compost-based biofertilizer contained $1 \%$ zeolite $+10 \%$ liquid inoculant.

\subsection{Chlorophyll content and $N$ uptake}

Chlorophyll unit, percentage of $\mathrm{N}$ in shoot and $\mathrm{N}$ uptake (mg/plant) of strawberry shoot were influenced by MCU doses and types (Table 4). The result showed that 2 $\mathrm{g}$ of MCU-II and $1 \mathrm{~g}$ of MCU-I increased the SPAD value compared to the control treatment. The plants treated with $2 \mathrm{~g}$ of MCU had the highest SPAD value.

Tabel 4. The effect of dose and microbes-coated urea on SPAD value, and $\mathrm{N}$ content and $\mathrm{N}$ uptake of 4 -week old strawberry shoots

\begin{tabular}{llll}
\hline Coated Urea Treatments & $\begin{array}{l}\text { SPAD } \\
\text { value }\end{array}$ & $\begin{array}{l}\text { Shoot N } \\
\text { content } \\
(\%)\end{array}$ & $\begin{array}{l}\text { Shoot N } \\
\text { uptake } \\
\text { (g/plant) }\end{array}$ \\
\hline 2 g of Urea (control) & $26.1 \mathrm{c}$ & $2.38 \mathrm{~b}$ & $0.07 \mathrm{~b}$ \\
1 g of Microbial Coated Urea -I & $25.9 \mathrm{~cd}$ & $2.47 \mathrm{a}$ & $0.06 \mathrm{~b}$ \\
2 g of Microbial Coated Urea -I & $29.1 \mathrm{~b}$ & $2.41 \mathrm{a}$ & $0.09 \mathrm{a}$ \\
1 g of Microbial Coated Urea -II & $24.8 \mathrm{~d}$ & $2.19 \mathrm{c}$ & $0.07 \mathrm{~b}$ \\
2 g of Microbial Coated Urea -II & $31.1 \mathrm{a}$ & $2.23 \mathrm{~b}$ & $0.07 \mathrm{~b}$
\end{tabular}

Numbers followed by the same letter didn't significantly differ

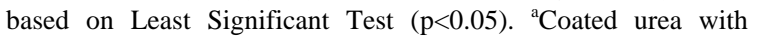
compost-based biofertilizer contained $5 \%$ zeolite $+5 \%$ liquid inoculant; ${ }^{\mathrm{b}}$ Coated urea with compost-based biofertilizer contained $1 \%$ zeolite $+10 \%$ liquid inoculant.

\section{Discussion}

The experiment found that the effect of MCU was mostly significant for root growth compared to the shoots. Increased root dry weight of MCU-treated plants compared to the control plants was possibly caused by root volume increment. Both Bacillus and Azotobacter produce phytohormones IAA, GA and CK (Hindersah et al., 2020a) which stimulate root growth. Plant treated with lower doses of MCU-I showed the intensive rooting compared to the control or higher doses of MCU.

Phytohormones play a central role on root growth. Plant has endogenous phytohormones, then the balance composition of the three phytohormones associated with well performance of shoot and root growth. Small quantities of IAA produced by soil microbes have been reported to increase root but high concentration inhibit root elongation (Kurepin et al., 2014). The better root growth might relate to the ability of all bacteria to synthesize the $\mathrm{CK}$ and GA. The CK is involved in the regulation of many processes in plant development (Kulaeva et al., 2002). The IAA positively interacts with GA in growth regulation, in which the concentration of GA is enhanced in the presence of IAA. The GA also plays an essential role in the normal development of roots, keeping the root long and slender (Tanimoto, 2005). In common, normal roots enable to uptake the water and nutrients optimally.

The MCU supports root growth indicated by higher R/S (Table 3) due to available $\mathrm{N}$ slow released from urea and Azotobacter as well. The effect of MCU on the delay of N release has not been yet reported, but coating the urea is already known as controlled-released way to slow down the $\mathrm{N}$ release (Bibi et al., 2016). The main ingredients of solid inoculant in this experiment were composted cow waste. Organic matter in the surface of urea has a function to prevent high temperature exposure to urea and hence reduce the ammonia volatilization. Microbial solid inoculant can minimize direct contact of water to urea and further reduce nitrate leaving the root zone. This agrees with the reduction of $27.5 \%$ in ammonia volatilization and $18.3 \%$ in nitrate leaching of neem-coated urea (Jadon et al., 2018).

The coco peat-based growth substrate used in this experiment contained average level of total $\mathrm{N}$ due to enrichment with animal manure, but Shanmugasundaram et al. (2013) state that coco peat contains very low N, P and potassium $(\mathrm{K})$; then $\mathrm{N}, \mathrm{P}$ and $\mathrm{K}$ supplement is considered to be applied. However, mixing coco peat in organic media enables improving the physical properties of the potted substrate and hence supports root growth in limited area of a pot (Singh et al., 2016). The good physical properties induce the growth of rhizobacteria utilized in coating the urea. Low $\mathrm{N}$ in coco peat induce nitrogenase activity to fix the dinitrogen $\left(\mathrm{N}_{2}\right)$ since the abundance of $\mathrm{N}$ limited the $\mathrm{N}$ fixation (Hoffman et al. 2014). On the other hand, high porosity of coco peat-based substrate cause urea leaching when excessive watering had taken place (Burger and Jackson, 2003; Wang et al., 2015).

Strawberry shoot parameters did not influence by MCU at any doses and composition compared to the control. The duration of our experiment was only one month since after that the seedling will be transplanted for strawberry production. A one-month experiment might be too short to demonstrate the effect of MCU on shoot parameters. Contrary to our results, positive effect of urea application combined with biofertilizer on plant height was reported for potted and hydroponic strawberry during 60-120 days (Rueda et al., 2016; Beer et al., 2017; Reddy and Goyal, 2020). In their study, application of biofertilizers and $\mathrm{N}$ fertilizer increased the plant height, plant spread, number of leaves per plant and crown diameter significantly. Our 
results indicated that the reduced dose of MCU maintains the crown diameter. In strawberry, crown as well as roots have an important role as carbohydrate reserve (Menzel and Smith, 2012). The crown size clearly affected strawberry yield under Florida conditions in two-year consecutive seasons (Torres-Quezada et al., 2015). Our strawberry seedling will be utilized in strawberry production; the crown size $>10 \mathrm{~mm}$ ensures total fruit number compared to $<10 \mathrm{~mm}$ (Torres-Quezada et al., 2015).

Only half and full doses of MCU-I increased shoot N content compared to control plant but SPAD value of full dose MCU treatment was higher than the control (Table 4). The Azotobacter fix $\mathrm{N}_{2}$ to ammonia which is then nitrify to nitrate by nitrifying bacteria (Fiencke et al. 2005). Mostly terrestrial plant uptake the nitrate as $\mathrm{N}$ source in the metabolisms (Chapin et al., 2002); with involving of specific transporter of nitrate, NRT (Nacry et al., 2013). Highest $\mathrm{N}$ content usually related to chlorophyll-a since the chlorophyll-a is substituted tetrapyrrole that contained four $\mathrm{N}$ atoms (Berg et al, 2002). The chlorophyll is a central photoreceptor for electron transport in photoautotrophic metabolisms (Berg et al, 2002) in order to generate the energy for plant growth. High $\mathrm{N}$ content of shoot of strawberry with MCU-I was due to constant supply on $\mathrm{N}$ and phosphate from rhizobacteria for roots uptake. Reducing urea fertilizer to $50 \%$ in lower dose of MCU-I apparently induced $\mathrm{N}$ fixation that needs a lot of ATP molecules since nitrogenase is sensitive to high available $\mathrm{N}$ of substrate (Hoffman et al., 2014). The presence of available $\mathrm{P}$ by phosphate solubilizing Bacillus may contribute the P supply for ATP formation. Both Bacillus species in this experiment produced extracellular phosphatase (Hindersah et al., 2020b) as a prominent mechanism to solubilize the organic $\mathrm{P}$ in growth substrate (Guang et al., 2008; Ambreen et al.,2020).

Although the strawberry has grown only for a month, Our experiment showed that half dose of MCU resulted in the similar value of root and shoot parameter (Table 1 and Table 2). This indicated that urea fertilizer dose can be saved up to $50 \%$. Delaying $\mathrm{N}$ released from coated urea might lead to increase the $\mathrm{N}$ efficiency used from fertilizer based on shoot $\mathrm{N}$ uptake (Mesquita et al., 2017).

The result showed that seedlings received half dose MCU-I and half dose of MCU-II have higher R/S at early growth compared to the control. Biofertilizer application integrated with urea play a significant role to increase strawberry rooting compared to the control. In early vegetative, good rooting and crown size of bare roots strawberry transplant plant ensure the strawberry biomass due to optimal N uptake (Tagliavini et al., 2005; Cocco et al., 2011). In Bandung Regency, the first harvest of strawberry fruit is commonly no later than 10 weeks after transplanting the bare-root strawberry transplant.

In general, lower doses of MCU-I was more effective to replace conventional urea in early growth of strawberry. The MCU was the urea coated with solid inoculant with compost as the main ingredients of carrier enriched with zeolite. The MCU-I contained 5\% zeolite while the MCUII contained only $1 \%$ zeolite. Higher content of zeolite in coating material of MCU-I can protect the urea from the humidity as well as slower urea hydrolysis and $\mathrm{N}$ release to soil. However, the result indicated that the $\mathrm{N}$ uptake of one individual plant was very low compared to applied urea and NPK fertilizer. This verifiy that N use efficiency (NUE) by seedling in soilless substrate might be low. Further experiment is needed to assess the NUE value.

Strawberry is an important horticultural product of Bandung and Bandung Barat Regency. Nowadays, the strawberry productivity is not as high as years before due to fertilization and seedling problem. The results of this greenhouse trial are the first information concerning the response of strawberry seedlings to reduced dose of chemical fertilizer application in Indonesia. However, next experiment is needed to verify the long-term effect of MCU doses and application method on NUE and plant growth during strawberry transplant production.

\section{Conclusion}

Urea fertilizer coated with solid biofertilizer composed of composted manure, 5\% zeolite and 5\% liquid bacterial inoculant increased root volume, root dry weight, root to shoot ratio and shoot $\mathrm{N}$ content significantly, but only full dose of that MCU formulation increased shoot $\mathrm{N}$ uptake and SPAD value. Compared to the control, MCU at any dose and formulation did not affect crown diameter, root length, plant height and shoot dry weight at 4 weeks after planting. The effect of urea coated with solid inoculant of Azotobacter and Bacillus was mostly increased root parameters compared to the shoots. However, MCU application resulted in $>20 \mathrm{~mm}$ of crown diameter which ensures the growth of transplant in strawberry production. Utilizing half dose of urea fertilizer coated with composted manure with $5 \%$ zeolite and $5 \%$ liquid inoculant is considered resulted in the increment of certain growth parameter of strawberry seeding until 4 weeks after treatment compared to a dose of conventional. This result indicated that utilizing microbial coated urea might lower the doses of urea applications up to $50 \%$.

\section{Acknowledgement}

The research was funded by Directorate General of Higher Education, Ministry of Education and Culture, Republic of Indonesia, in 2020.

\section{References}

Ahmad S, Imran M, Hussain S, Mahmood S, Hussain A and Hasnain M. 2017. Bacterial impregnation of mineral fertilizers improves yield and nutrient use efficiency of wheat. $J$ Sci Food Agric., 97(11):3685-3690.

Ambreen A, Yasmin A and Aziz S. 2020. Isolation and characterization of organophosphorus phosphatases from Bacillus thuringiensis MB497 capable of degrading Chlorpyrifos, Triazophos and Dimethoate. Heliyon, 6(7): e04221.

Ameri A, Tehranifar A, Davarynejad GH and Shoor M. 2012. Effect of substrate and cultivar on growth characteristic of strawberry in soilless culture system. $J$ Biol Environ Sci, 6(17):181-188.

AOAC. (2012). Official Methods of Analysis, $19^{\text {th }}$ ed. Association of official analytical chemist, Washington D.C., USA.

Bhattacharyya PN and Jha D.K. 2012. Plant growth-promoting rhizobacteria (PGPR): emergence in agriculture. World $J$ Microbiol Biotechnol., 28:1327-1350.

Bibi S, Saifullah, Naeem A and Dahlawi S. 2016. Environmental impacts of nitrogen use in agriculture, nitrate leaching and 
mitigation strategies. In: Hakeem KR et al. (Eds.), Soil Science: Agricultural and environmental prospectives. Springer International Publishing, Switzerland, pp. 131-157.

Beer B, Kumar S, Gupta AK, Syamal MM. 2017. Effect of organic, inorganic and bio-fertilizer on growth, flowering, yield and quality of strawberry (Fragaria $\times$ Ananassa Duch.) cv. Chandler. Int J Curr Microbiol App Sci., 6(5):2932-2939.

Berg JM, Tymoczko JL and Stryer L.2002. Biochemistry. 5th ed. W H Freeman, New York

Burger $\mathrm{M}$ and Jackson LE. 2003. Microbial immobilization of ammonium and nitrate in relation to ammonification and nitrification rates in organic and conventional cropping systems. Soil Biol Biochem., 35(1):29-36.

Chapin FS, Matson PA and Mooney HA. 2002. Terrestrial plant nutrient use. In: Principles of terrestrial ecosystem ecology. Springer, New York, NY. pp. 176-196

Cocco C, Andriolo JL, Cardoso FL, Erpen L and Schmitt OJ. 2011. Crown size and transplant type on the strawberry yield. Sci. Agric., 68(4):489-493.

Fan XH, Li YC and Alva AK. 2011. Effects of temperature and soil type on ammonia volatilization from slow-release nitrogen fertilizers. Comm Soil Sci Pl Anal., 42(10):1111-1122.

Fiencke, C., Spieck, E., \&Bock, E. (2005). Nitrifying Bacteria. In Werner $\mathrm{D}$ and Newton WE (Eds.). Nitrogen fixation in Agriculture, Forestry, Ecology, and the Environment. Springer, Netherlands, pp 255-276.

Fitriatin BN, Fauziah D, Fitriani FN, Ningtyas DN, Suryatmana P, Hindersah R, Setiawati MR and Simarmata T. 2020. Biochemical activity and bioassay on maize seedling of selected indigenous phosphate-solubilizing bacteria isolated from the acid soil ecosystem. Open Agric., 5(1):300-304.

Gastal,G G. Lemaire. 2002. N uptake and distribution in crops: an agronomical and ecophysiological perspective. J Exp Bot., 53(370): 789-799.

Guang-Can TAO, Shu-Jun T, Miao-Ying CAI and Guang-Hui XIE. 2008. Phosphate-solubilizing and mineralizing abilities of bacteria isolated from soils. Pedosphere, 18:515-523.

Güler S, Macit I, Koç A and Ibrikci H. 2006. Estimating Leaf nitrogen status of strawberry by using Chlophyll meter reading. $J$ Biol Sci., 6(6):1011-1016.

Hindersah R, Setiawati MR, Fitriatin BN, Suryatmana P and Asmiran P. 2019. Chemical characteristics of organic-based liquid inoculant of Bacillus spp. IOP Conf Ser: Earth Environ Sci., 393:012005.

Hindersah R, Setiawati MR, Fitriatin BN, Rahmadina I and Risanti RR. 2020a. Organic carrier-based inoculant of Bacillus and Azotobacter consortium. Test Engineer Manag, 82:7464 7470 .

Hindersah R, Setiawati MR, Asmiran P and Fitriatin BN. 2020b. Formulation of Bacillus and Azotobacter consortia in liquid cultures: preliminary research on microbes-coated urea. Int $J$ Agric Sys., 8(1):1-10.

Hindersah R, Rahmadina I, Harryanto R, Suryatmana P and Arifin M. Bacillus and Azotobacter counts in solid biofertilizer with different concentration of zeolite and liquid inoculant. IOP Conf. Series: Earth and Environ Sci., 667(2021): 012010.

Hoffman BM, Lukoyanov D, Yang Z-Y, Dean DR and Seefeldt LC. 2014. Mechanism of nitrogen fixation by nitrogenase: the next stage. Chem Rev., 114(8): 4041-4062.

Jadon P, Selladurai R, Yadav SS, Coumar MV, Dotaniya ML, Singh AK, Bhadouriya J and Kund S. 2018. Volatilization and leaching losses of nitrogen from different coated urea fertilizers. $J$ Soil Sci Pl Nutr., 18(4):1036-1047.
Kulaeva ON and Kusnetsov VV. 2002. Recent advances and horizons of the cytokinin studying. Russ. J Plant Physiol., 49:561-575.

Kurepin LV, Zaman M and Pharis RP. 2014. Phytohormonal basis for the plant growth promoting action of naturally occurring biostimulators. J Sci Food Agric., 94(9):1715-22.

Mishra AN and Tripathi VK. 2011. Influence of different levels of Azotobacter, PSB alone and in combination on vegetative growth, flowering, yield and quality of strawberry cv. Chandler. Int J Appl Agric Res., 6(3):203-210.

Menzell CM and Smith, L. Relationship between the levels of non-structural carbohydrates, digging date, nursery-growing environment, and chilling in strawberry transplants in a subtropical environment. Hort Sci., 47(4): 459-464, 2012.

Mesquita GL, Zambrosi FCB, Cantarella H. 2017. A practical approach for assessing the efficiency of coated urea on controlling nitrogen availability. Bragantia, 76(2): p.311-317.

Mustafa HM and Hayder G. 2021. Performance of Salvinia molesta plants in tertiary treatment of domestic wastewater. Helycon, 7(2021): e06040.

Nacry P Bouguyon E Gojon A . 2013. Nitrogen acquisition by roots: physiological and developmental mechanisms ensuring plant adaptation to a fluctuating resource. Pl Soil, 370: 1-29.

Palupi NE, Aji TG, Kurnilasari D dan Sutopo. 2017. Efektivitas Dosis Dan Aplikasi Pupuk Npk Majemuk Pada Fase Vegetatif Pada Tanaman Strawberry (Fragaria $\mathrm{x}$ ananassa Duchesne). Agrisaintifika, 1(2):109-116. In Indonesian, abstract in English.

Pang W, Crow WT, Luc JW, McSorley R, Giblin-Davis RM, Kenworthy KE and Kruse JK. Comparison of water displacement and WinRHIZO software for plant root parameter assessment. $\mathrm{Pl}$ Dis, 95(10):1308-1310.

Raja WH, Kumawat KL, Sharma OC, Sharma A, Mir JI, Nabi SUN, Lal S and Qureshi I. 2018. Effect of different substrates on growth and quality of strawberry cv. chandler in soilless culture. The Pharma Innov J., 7(12): 449-453.

Reddy GC and Goyal RK. 2020. Growth, yield and quality of strawberry as affected by fertilizer $\mathrm{N}$ rate and biofertilizers inoculation under greenhouse conditions. J Pl Nutr., 44(1):46-58.

Rodriguez-Salazar J, Moreno S and Espín G. 2017. LEA Proteins are involved in cyst desiccation resistance and other abiotic stresses in Azotobacter vinelandii. Cell Stress Chaperon, 22: 397408.

Rubio EJ, Montecchia MS, Tosi M, Cassán FD, Perticari A and Correa OS. 2013. Genotypic characterization of Azotobacteria isolated from Argentinean soils and plant-growth-promoting traits of selected strains with prospects for biofertilizer production. Sci World J., 2013: 519603.

Saeid A, Prochownik E and Dobrowolska-Iwanek J. 2018. Phosphorus solubilization by Bacillus Species. Molecules, 23:2897

Shanmugasundaram R, Jeyalakshmi T, Mohan SS, Saravanan M, Goparaju A and Murthy PB. 2013. Coco peat - An alternative artificial soil ingredient for the earthworm toxicity testing. $J$ Toxicol Environ Health Sci., 6(1):5-12.

Shternshis MV, Belyaev AA, Shpatova TV and Lelyak AA. 2015. Influence of Bacillus spp. on strawberry gray-mold causing agent and host plant resistance to disease. Contemp Probl Ecol., 8:390396.

Singh S, Dubey RK, Kukal SS. 2016. Nitrogen supplemented cocopeat-based organic wastes as potting media mixtures for the growth and flowering of chrysanthemum. J Comm Soil Sci Pl Anal., 47(16): 1856-1865. 
Rueda D, Valencia G, Soria N, Rueda BR, Manjunatha B, Kundapur RR and Selvanayagam M. 2016. Effect of Azospirillum spp. and Azotobacter spp. on the growth and yield of strawberry (Fragaria vesca) in hydroponic system under different nitrogen levels. J Appl Pharma Sci., 6(1):048-054.

Tan IS and Ramamurthi KS. 2014. Spore formation in Bacillus subtilis. Environ Microbiol Repos., 6(3): 212-225.

Tanimoto E. 2005. Regulation of root growth by plant hormones-roles for auxin and gibberellin. Crit Rev Pl Sci., 24(4): 249-265.

Tagliavini M, Baldi E, Lucci P, Antonelli M, Sorrenti G, Baruzzi $\mathrm{G}$ and Faedi W. 2005. Dynamics of nutrients uptake by strawberry plants ( Fragaria $\times$ Ananassa Dutch.) grown in soil and soilless culture. Euro J Agron., 23(1):15-25.

Tatlier M, Munz G and Henning SK. 2018. Relation of water adsorption capacities of zeolites with their structural properties. Micropor Mesopor Mat, 264:(70-75).
Torres-Quezada EA, Zotarelli L, Whitaker VM, Santos BM and Hernandez-Ochoa I. Initial crown diameter of strawberry bareroot transplants affects early and total fruit yield. Hort Technol., 25(2):203-208

Wahyuni S, Indratin, Sulaeman E and Ardiwinata AN. 2016. Activated carbon coated urea enriched with microbial consortia accelerates the decrease of heptachlor insecticide residue in paddy fields. Informatika Pertanian, 25(2):155-162. In Indonesian, abstract in English

Wang B, Lai T, Huang Q-W, Yang X-M and Shen Q-R. 2009. Effect of $\mathrm{N}$ fertilizers on root growth and endogenous hormones in strawberry. Pedosphere, 19(1):86-95.

Wang H, Gao J-e, Li X-h, Zhang S-l and Wang H-j. 2015. Nitrate accumulation and leaching in surface and ground water based on simulated rainfall experiments. PLoS ONE, 10(8): e0136274.

Wei F, Hu X and Xub X. 2016. Dispersal of Bacillus subtilis and its effect on strawberry phyllosphere microbiota under open field and protection conditions. Sci Rep., 6: 22611. 